\title{
The Influence of Modeling on Science Self-efficacy among Middle School Stu- dents
}

\section{Dr. Cara N. Morton, Washington State University}

Cara has three years of structural engineering design experience and has been teaching civil engineering classes since 2014 at Washington State University. Her breadth of design ranges from waterfront structures in the Gulf of Mexico to seven story concrete buildings governed by seismic loads in Seattle, WA. She is pursuing material science related research regarding durable materials for construction. Currently, she serves as Clinical Professor at Washington State University teaching the Integrated Civil Engineering Design class and with regards to engineering education, specializes in easing the school to work transition.

\section{Dr. Kira J. Carbonneau, Washington State University}

Dr. Kira J. Carbonneau, is an Assistant Professor in Educational Psychology, with five years of K-8 teaching experience. Dr. Carbonneau's area of expertise is in the efficacy of instructional practices in mathematics and science as well as research methodology. She has experience consulting on statistical analyses, research design, measurement analysis, and assessment development in various areas including teacher education, math education, socio-emotional learning and motivational constructs. Her work has been published in Journal of Educational Psychology, Contemporary Educational Psychology and Journal of Experimental Education, among other venues. 


\title{
The influence of modeling on science self-efficacy among middle school students
}

(evidence based practice paper: teaching approaches)

\begin{abstract}
Engineering lacks a presence in the k-12 classroom except through project or design based curriculum, which is primarily used to teach science concepts. Educators often recommend including instructional strategies that create opportunities to increase a students' self-efficacy to improve student achievement in science. Previous research supports science self-efficacy as being positively associated with achieving science literacy (Bryan, Glynn, \& Kittleson, 2011) and science achievement (Britner \& Pajares, 2001). This study examines if exposing students to young model “engineering experts” would impact middle schoolers’ science self-efficacy. If so, the motivation for k-12 teachers to invite engineers into their classroom is two fold. It increases students' awareness of engineering careers as well as increases student's achievement in science. But would such a short intervention have an impact? Students were surveyed at the beginning and end of a one day event at Washington State University, which included "engineering experts" who interacted with the students in small groups (60 min total). Results from the RepeatedMeasures Analysis of Variance (RM-ANOVA) demonstrated that participants reported higher perceived ability to engage in scientific learning processes $(d=.17)$ and in science learning behaviors $(d=0.15)$. Both theoretical and practical implications are discussed.
\end{abstract}

\section{Objective}

Self-efficacy is the judgement an individual makes regarding their ability to perform various tasks and this judgement is domain and task specific (Bandura, 1977, 1982). Since the way in which people act, think, and feel, is a direct reflection of their own beliefs in their 
capabilities, learners' beliefs promote both engagement and learning (Linnenbrink \& Pintrich, 2003), as well as long-term achievement (Parker, Marsh, Ciarrochi, Marshall, \& Abduljabbar, 2014). Bandura (1995) explained that those who have a robust belief in their capabilities exert greater effort needed to succeed, and strong perseverance contributes to performance accomplishments. Additionally, perceived beliefs of ability can be increased through modeling or observation of behaviors and actions demonstrated by others.

Empirical studies support science self-efficacy as being positively associated with achieving science literacy and science-related choices throughout schooling and future careers (Andrew, 1998; Gwilliam \& Betz, 2001). Lacking from the literature are examinations of the effects of instructional practices on science self-efficacy. Therefore, the purpose of the present study was to expand on the current literature regarding science self-efficacy (Bryan et. al., 2011) by examining whether exposing students to young model "engineering experts" would impact their science self-efficacy.

\section{Theoretical Framework}

\section{Self-efficacy in the Academic Context}

Self-efficacy, as a personal cognitive factor and a key component of social cognitive theory (SCT), refers to people's beliefs about their ability to perform a given task successfully (Bandura, 1997). Researchers believe that learners' beliefs promote both engagement and learning (Linnenbrink \& Pintrich, 2003). Specifically, studies show that people’s beliefs contribute significantly to human motivation and attainments (Bandura, 1992; Pajares \& Miller, 1994; Schunk, 2003). Secondly, studies indicate self-efficacy as a positive predictor of academic performance (Bandura, 1997; Schunk, 1991; Bruning, Dempsey, Kauffman, McKim, \& 
Zumbrunn, 2013; Sanders-Reio, Alexander, Reio, \& Newman, 2014) as well as long-term achievement (Parker et. al., 2014).

Self-efficacy is domain and task specific. The following section specifically discusses self-efficacy in science: 1) the established positive relationship between science self-efficacy and achievement in science; 2) factors that impact science self-efficacy, specifically prior successes and modeling of behaviors in academic settings; and 3) gender differences regarding the relationship between sources of self-efficacy and science self-efficacy.

\section{Science Self-Efficacy and Achievement.}

Theoretically, self-efficacy in science is expected to be a powerful predictor of science achievement. McMillan \& Forsyth (1991) theorized that science self-efficacy might be the most important key to success, and predicts that students with high science self-efficacy are more willing to take and persevere through difficult science courses. For example, the science selfefficacy of college students has been associated with the amount of time spent studying science and decisions to pursue careers in science (Andrew, 1998; Gwilliam \& Betz, 2001). Science self-efficacy has also been positively correlated with science literacy achievement and involvement with science activities (Bryan et. al., 2011; Lau \& Roeser, 2002). Kupermintz (2002) found that student science self-efficacy was the strongest motivational predictor of achievement in science.

\section{Sources of Science Self-Efficacy}

According to Bandura (1982), self-efficacy can originate from: 1) previous successes within the domain; and 2) observation of success in a peer with perceived similar capabilities. Researchers have reported significant correlations ranging from .20 to .78 between these two sources of self-efficacy and overall self-efficacy (Britner, 2008; Usher \& Pajares, 2006). When 
studied in isolation, previous success with science tasks has been demonstrated to correlate with student self-efficacy in science (Sungur \& Güngören 2009). Britner and Pajares (2006) surveyed 319 middle school science students and found medium-sized relationships between science selfefficacy and science literacy achievement.

Additionally, Schunk (2003) noted that exposure to modeling or observation of a behavior or an action (e.g., adult demonstrating how to do something in real life) impacts selfefficacy because when an individual observes others perform a task they implicitly assume they possess the necessary skills to accomplish it as well. Therefore, students that are exposed to model “engineering experts” via presentation at a science competition, will demonstrate higher science self-efficacy based on their perceptions of their ability to complete similar tasks observed. Schunk and Hanson (1985) conducted a study to investigate the role peers play on children's self-efficacy and math achievement. Students were exposed to either mastery or coping behaviors modeled by peers while solving math problems. The results provide support suggesting that exposure to modeling of a specific behavior increases self-efficacy and student achievement. Berger (2006) argued that when learners are given the opportunity to observe others performing similar tasks, they can become motivated to engage in various activities because of their belief in their ability to accomplish the task.

\section{Gender Differences}

While most of the prior research examining sources of self-efficacy involve math, a few researchers have investigated the sources of science self-efficacy in isolation. Recently, Britner (2008) studied 502 high school science students to investigate the degree that each of the sources of self-efficacy correlated with science self-efficacy. The results demonstrated gender differences, for male students, direct past experience was the only significant predictor of science 
self-efficacy with a medium-sized relationship. For female students, past experiences, vicarious experiences, social persuasion and physiological state were all small significant predictors of science self-efficacy. Persuasion from an authority figure was the strongest positive predictor for females. Science self-efficacy was also a significant predictor of achievement within science courses.

\section{Purpose of the Present Study}

The purpose of the present study was to determine if exposing students to young model “engineering experts” would impact their science self-efficacy. Specifically, this study seeks to determine if providing middle school students with the opportunity to interact with professional engineers and passionate engineering students through three twenty minute demonstrations to groups of fifteen or less students would increase their science self-efficacy. We predicted that exposure to different engineering labs and graduate student models would increase students' selfefficacy from their initial rating. Also, from the current literature we expect that female students' self-efficacy will benefit more from observing engineering labs and science models than male students resulting in greater perceived self-efficacy. If this prediction is true, then an engineer has greater impact with a one time, one hour visit to the classroom than might have been assumed. As such, these results would validate the role of "engineering experts" in the classroom to not only introduce a new world of world of careers that students are often unaware of, but increase science achievement for the class and help close the gender gap in STEM careers.

\section{Methodology}

\section{Sample and Design}

The sample consisted of 75 middle school students with an average age of $12.2(S D=$ 1.3) and $53.3 \%$ of the sample were girls. Approximately $61 \%$ of the students were participating 
in the competition (Future City Competition) as a class requirement. The remaining approximately 39\% of students were voluntarily participating (eg, after school club, library activity). Students came from across the western and eastern regions of Washington and Idaho, respectively. Students were coming to a Washington State university to compete in a regional science competition and were notified of the opportunity to participate in the study prior to coming onto campus. The research design is exploratory in nature and is a pre/post design with no manipulation.

\section{Instrument: Science self-efficacy questionnaire}

This measure contained 10 items addressing participant's self-efficacy in science, which was broken down into: learning processes and learning behaviors. This measure was modified using Bandura’s (2006) instructions on constructing self-efficacy items and was adapted from a math inventory for young students (Pajares \& Miller, 1995). Five items related to science learning processes, which asked participants to rate their perceived ability to engage in science learning. For example, participants rated the statements I can ask good science questions on a scale from 0 (I cannot do it) to 10 (I can do it). The remaining five items were related to science learning behaviors, which asked participants to rate their perceived ability in concrete learning behaviors such as I can finish my science homework. The individual scores for each set of five items were averaged together to produce a two science self-efficacy scores prior to being exposed to “engineering expert” models as well as after. The inventory was taken before viewing expert models (process: $\alpha=.92$; behaviors: $\alpha=.90$ ) as well as after (process: $\alpha=.85$; behaviors: $\alpha=.91)$. 


\section{Procedures}

Prior to arriving to campus parents and students were notified of the opportunity to complete a pre-post survey asking students to rate their ability to do science activities. Upon arrival to campus consent forms were collected and through out the morning activities students were asked to complete the 10-item survey. The morning activity was primarily the Future City model presentation and students waiting for their turn to compete participated in small hands on challenges such stacking books on paper houses, scavenger hunts within the engineering classrooms and some hands on technology such as google view goggles. After the completion of the morning activities, students were rotated through a series of three engineering demonstrations which were labs or science club presentations. These included a soils lab, materials lab, robot club (one with a mock BB8 and another with a flying drone), formula one racecar team, architecture-engineering-construction (AEC) club and (American Society for Civil Engineers) ASCE's steel bridge building team. In order to move ninety students through tours in one and half hours with fifteen or less students per group, the teams were assigned to only three twenty minute demonstrations, but many more were offered. All presentations were delivered by graduate students, most of which were student clubs, with the specific focus of exposing students to different fields of engineering.

There was some fun competition that developed between the different fields of engineering. As the ASCE students were showing the middle school students their lab for welding and a video of the steel bridge building race at their last competition, a drone flew in

over the floor-sitting $6^{\text {th }}-8^{\text {th }}$ grader students' heads. The middle school students awed at the drone and could not help but to watch and follow it as it headed down the hall to the mechanical engineering department. When the ASCE students saw they were losing the kids' interests they 
started chanting “civil rocks... civil rocks”. The students quickly re-engaged and took sides as to which was cooler: civil engineers or mechanical engineers.

Students were rotated through three varying presentations that were intended to be relatively intimate and encourage one on one interaction between the kids and the college students (“engineering experts”). The primary purpose being to introduce multiple fields of engineering to the middle schoolers, give them access to "engineering experts” and demonstrate to them that their dreams for a better future are not just "pie in the sky dreams”, but that universities have the resources to help them achieve their design to make this world a better place. After this inspiration, they were then asked to complete the 10-question survey again.

\section{Analysis}

For both self-efficacy constructs, learning processes and learning behaviors a RepeatedMeasures Analysis of Variance (RM-ANOVA) was used to analyze differences in participants’ perception, with gender (boy vs. girl) as the between-subject factor and time as a within-subject factor.

\section{Results}

\section{Science Learning Processes}

The science learning outcome measure asked participants about their perceived ability to engage in science learning processes such making scientific hypotheses. Results indicate a significant within-subjects effect of time $(F(1,71)=6.9, p=.010)$. Overall, all participants after attending engineering presentations increased their perceived ability to engage in scientific learning processes, $d=.17$. However, the between-subject effect of gender and the interaction between gender and time were not significantly significant. The mean and standard deviations are in Table 1. 


\section{Science Learning Behaviors}

Analogous to the learning processes outcome, participants' perception of their ability to engage in the science learning behaviors such as finishing science homework was increased after participating in the day's activity. This was indicated by a significant within-subjects effect of time $(F(1,71)=5.8, p=.018, d=.15)$. No significant differences were seen between boys and girls and the interaction between gender and time were not statistically significant.

\section{Discussion}

The present study examined whether exposing students to engineering labs and science club presentations would impact their self-efficacy in science related tasks. The results indicate that students' science self-efficacy, as measured by science learning processes and learning behaviors, increased after observing science presentations by college students. However, no statistical significance was obtained for gender and the interaction between gender and time on science self-efficacy. Indicating that the gender did not influence participants' rating of selfefficacy as is often predicted by the literature.

The practical implications of these findings suggest that exposure to "engineering expert" models could influence children's beliefs in their own science abilities and should be considered as an instructional approach to increasing students' motivation towards engaging in science. A limitation of this study is that students were not interviewed regarding perception and selfreported their self-efficacy. In addition, no manipulation of types of demonstrations or model characteristics was done, but could be the basis for future work. Future studies should also be considered using cognitive interviews or exit-slips to determine if the increase in perceived selfefficacy is a result of exposure to "engineering experts". 
Table 1. Means and Standard Deviation by Time and Gender

\begin{tabular}{cccc}
\hline & Girls & Boys & Total \\
\hline & \multicolumn{3}{c}{ Science Learning Processes } \\
\hline \multirow{2}{*}{ Time 1 } & 7.5 & 7.5 & 7.6 \\
& $(1.7)$ & $(1.7)$ & $(1.8)$ \\
Time 2 & 8.0 & 8.4 & 8.4 \\
& $(1.4)$ & $(1.2)$ & $(1.5)$ \\
Total & 7.8 & 7.9 & 8.0 \\
& $(1.6)$ & $(1.4)$ & $(1.5)$ \\
\hline & \multicolumn{3}{c}{ Science Learning Behaviors } \\
\hline \multirow{2}{*}{ Time 1 } & 7.4 & 7.3 & 7.5 \\
& $(1.4)$ & $(1.7)$ & $(1.6)$ \\
Time 2 & 7.9 & 8.1 & $(1.1)$ \\
& $(1.2)$ & $(1.2)$ & 7.8 \\
Total & 7.7 & 7.7 & $(1.3)$ \\
\end{tabular}




\section{Science Self-Efficacy Questions}

Please answer the following questions to the best of your ability.

1. What year were you born?

2. What is your gender? (circle one) Male Female

3. What is your ethnicity?

4. What grade will you be starting in August?

Please rate how certain you are that you can do each of the things described below by circling the number:

I can learn science.

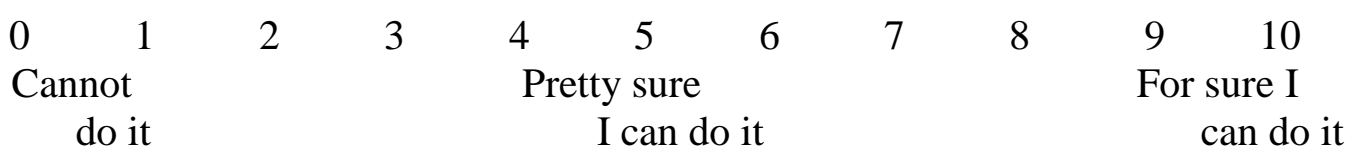

I can finish my science homework.

$\begin{array}{ccccccccc}0 \quad 1 & 2 & 3 & 4 & 5 & 6 & 7 & 8 & 9 \begin{array}{c}10 \\ \text { Cannot } \\ \text { do it }\end{array}\end{array}$

I can get myself to study science when there are other interesting things to do.

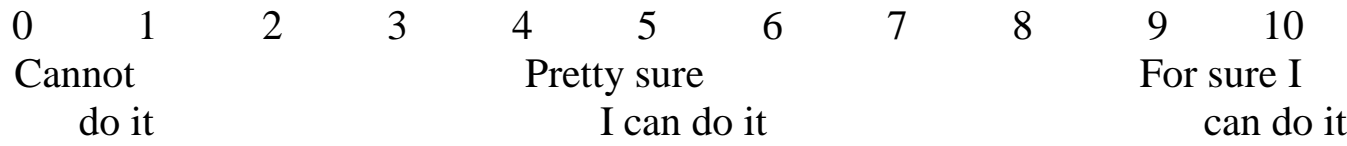

I can concentrate on science during class.

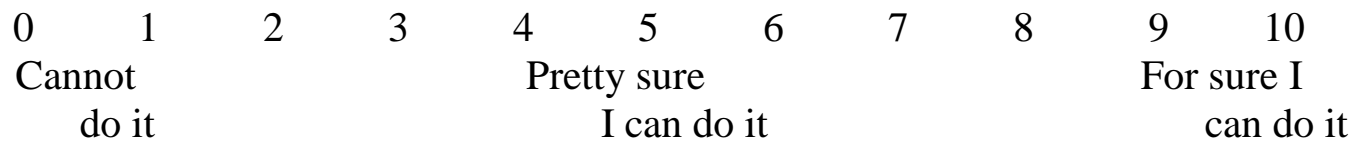

I can take good notes during science instruction.

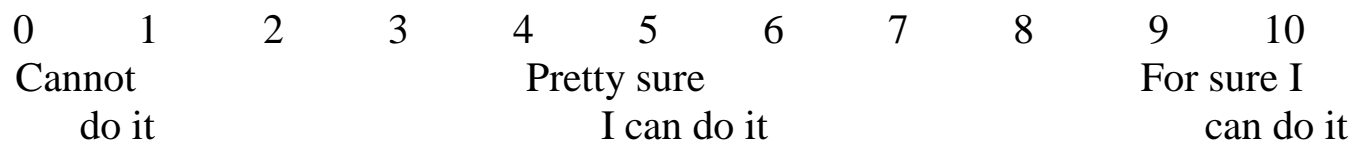


I can design science experiments well.

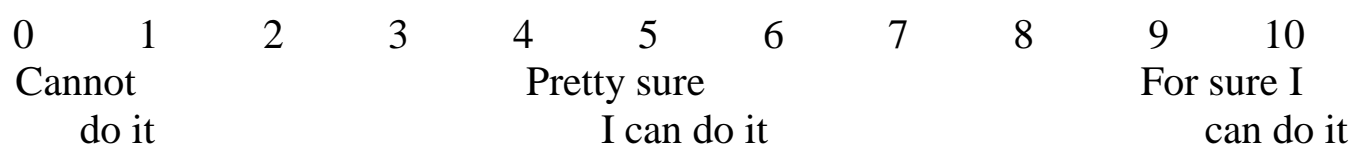

I can ask good science questions.

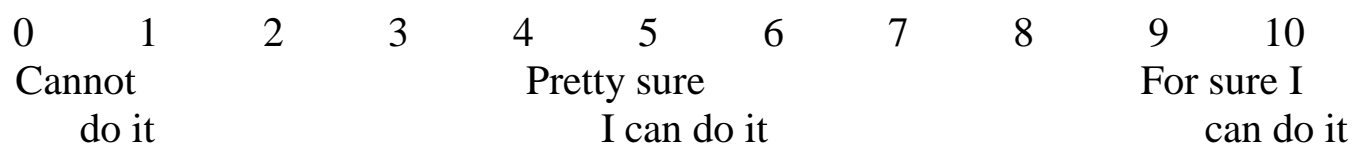

I can do science inside and outside of school.

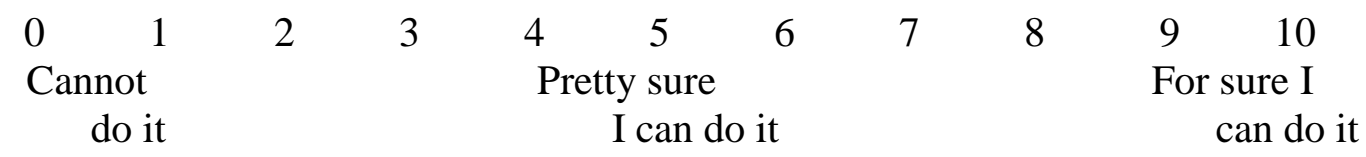

I can make a good scientific hypothesis.

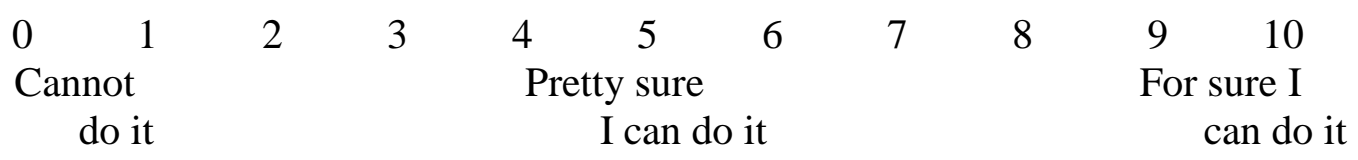

I can get myself to do my science school work.

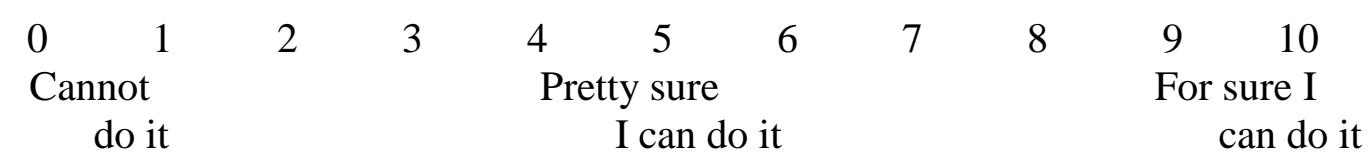




\section{References}

Andrew, S. (1998). Self-efficacy as a predictor of academic performance in science. Journal of advanced nursing, 27(3), 596-603.

Bandura, A. (1977). Social learning theory. Englewood Cliffs, NJ: Prentice-Hall

Bandura, A. (1982). Self-efficacy mechanism in human agency. American Psychologist, 37, 122-147.

Bandura, A. (1992). Exercise of personal agency through the self-efficacy mechanism. In R. Schwarzer (Ed.). Self-efficacy: Thought control of action (pp.3-38). Washington, DC: Hemisphere.

Bandura, A. (1995). Exercise of personal and collective changing societies. In A. Bandura (Ed.), Self-efficacy in changing societies (pp. 1-45). New York, NY: Cambridge University Press.

Bandura, A. (1997). Self- efficacy: The exercise of control. New York, NY: W. H. Freeman and Company.

Bandura, A. (1997). Self-efficacy: the exercise of control. New York: Freeman.

Bandura, A. (2006). Guide for constructing self-efficacy scales. In T. Urdan, \& F. Pajares (Eds.), Self-efficacy believes of adolescents (pp. 307-337). Greenwich, CT: Information Age.

Berger, K. S. (2006). The developing person: Through childhood and adolescence (7th ed.). New York, NY: Worth Publishers

Britner, S. L. (2008). Motivation in high school science students: A comparison of gender differences in life, physical, and earth science classes. Journal of Research in Science Teaching, 45(8), 955-970. 
Britner, S. L., \& Pajares, F. (2001). Self-efficacy beliefs, motivation, race, and gender in middle school science. Journal of women and Minorities in Science and Engineering, 7(4).

Bruning, R., Dempsey, M., Kauffman, D. F., McKim, C., \& Zumbrunn, S. (2013). Examining dimensions of self-efficacy for writing. Journal of Educational Psychology, 105(1), 2538.

Bryan, R. R., Glynn, S. M., \& Kittleson, J. M. (2011). Motivation, achievement, and advanced placement intent of high school students learning science. Science Education, 95, 10491065.

Gwilliam, L. R., \& Betz, N. E. (2001). Validity of measures of math-and science-related selfefficacy for African Americans and European Americans. Journal of Career Assessment, 9(3), 261-281.

Kupermintz, H. (2002). Affective and conative factors as aptitude resources in high school science achievement. Educational Assessment, 8(2), 123-137.

Lau, S., \& Roeser, R. W. (2002). Cognitive abilities and motivational processes in high school students' situational engagement and achievement in science. Educational Assessment, 8(2), 139-162.

Linnenbrink, E. A., \& Pintrich, P. R. (2003). The role of self-efficacy Beliefs in student engagement and learning in the classroom. Reading \&Writing Quarterly, 19(2), 119-137. DOI: 10.1080/10573560308223.

McMillan, J. H., \& Forsyth, D. R. (1991). What theories of motivation say about why learners learn. New directions for teaching and learning, 1991(45), 39-52. 
Pajares, F., \& Miller, M. D. (1994). Role of self-efficacy and self-concept beliefs in mathematical problemsolving: A path analysis. Journal of Educational Psychology, 86, 193-203.

Parker, P. D., Marsh, H. W., Ciarrochi, J., Marshall, S., \& Abduljabbar, A. S. (2014). Juxtaposing math self-efficacy and self-concept as predictors of long-term achievement outcomes. Educational Psychology, 34(1), 29-48.

Sanders-Reio, J., Alexander, P. A., Reio, T. G., \& Newman, I. (2014). Do students' beliefs about writing relate to their writing self-efficacy, apprehension, and performance?. Learning and Instruction, 33, 1-11.

Schunk, D. H. (1991). Self-efficacy and academic motivation. Educational Psychologist, 26(34), 207-231.

Schunk, D. H. (2003). Self-efficacy for reading and writing: Influence of modeling, goal setting, and self-evaluation. Reading \&Writing Quarterly, 19(2), 159-172.

Schunk, D. H., \& Hanson, A. R. (1985). Peer models: Influence on children's self-efficacy and achievement. Journal of Educational Psychology, 77(3), 313.

Sungur, S., \& Güngören, S. (2009). The role of classroom environment perceptions in selfregulated learning and science achievement. Elementary Education Online, 8(3), 883900.

Usher, E. L., \& Pajares, F. (2006). Sources of academic and self-regulatory efficacy beliefs of entering middle school students. Contemporary Educational Psychology, 31(2), 125141. 